\title{
線画の再認記憶における非対称的混同効果'
}

\author{
九州大学 内野八潮 2 箱田裕司・山田奈津子
}

Asymmetric confusability effects in recognition memory of line drawings

Yashio Uchino, Yuji Hakoda (Graduate School of Human-Environment Studies, Kyushu University, Hakozaki, Higashiku, Fukuoka 812-8581) and Natsuko Yamada (Department of Cognitive Psychology, Faculty of Letters, Kyushu University, Hakozaki, Higashi-ku, Fukuoka 812-8581)

Experiment 1 and 2 examined the effect of addition or deletion changes in a picture recognition test. Addition and deletion applied to original pictures were referred to deviation change, and addition to deleted pictures or deletion from added pictures was referred to restoration change. In Experiment $1 \quad(n=40)$, elaborative detailed information contained in line drawings of scenes was changed whereas one of major features in a single object was changed in Experiment $2(n=36)$. In the test phase, participants indicated whether each test picture was changed or not from the picture they had seen in the study phase. Deviation change had a greater effect on detection performance than restoration only in Experiment 2. Additions were easily detected than deletions only in deviation change in Experiment 2. In Experiment 3, 51 participants rated impression of added or deleted pictures used in Experiment 2. Impression of added pictures was significantly different from that of deleted in 3 factors. These results suggest that superiority of additions over deletions might be due to their different impression change.

Key words: recognition memory, additions or deletions, impression, asymmetric confusability effect, picture memory.

線画の再認課題においては一般に，学習刺激に何か 特徴が追加されたときのほうが，何か特徵が削除され たときよりも気づかれやすいこと（非対称的混同効 果) が多く報告されている（Agostinelli，Sherman, Fazio, \& Hearst, 1986; Miranda, Jackson, Bentley, Gash, \& Nallan, 1992; Nallan, Bentley, Carr, Lyons, Moore, \& Underhill, 1994; Pezdek, Maki, ValenciaLaver, Whetstone, Stoeckert, \& Dougherty, 1988).

Agostinelli et al. (1986) は対象物の線画を用い, 学習刺激に対象物の一つの要素を追加した刺激のほう が，学習刺激から一つの要素を削除した刺激よりもよ く再認されることを発見した。彼らは再認のプロセス を記憶表象と知覚表象の比較であるとみなし, Tversky（1977）の類似性判断モデルから，変化の検 出はその比較の方向に依存するという仮説をたてた. つまり，二つの表象のうち比較が始まる基点となる表 象が差異的特徴を含むとき，その変化はより検出され る。具体的には，テスト刺激が差異的特徵を含むのが

\footnotetext{
本研究は, 平成 10 年度文部省科学研究費（基盤研究(B), 課題番号 09410027 ，代表者・箱田裕司）の補助を受けた。

本研究の基本的発想を国際医療福祉大学の今井四郎先生と の私信をと扔して得ることができたことに深く感謝致します。 また, 実験 2 で用いた刺激のご提供を頂きました島根大学の松 川順子先生に深く感謝致します。
}

追加変化，学習刺激が差異的特徵を含むのが削除変化 である。彼らは，テスト刺激から学習刺激に比較が進 むと想定される条件では追加変化が, 逆に学習刺激か らテスト刺激へ比較が進むと想定される条件では削除 変化がより検出されたことを示し，仮説を裏づけた。

一方, Pezdek et al. (1988) は単純・複雑刺激（複 雑刺激は単純刺激に詳細情報を加えたもの）を用いた 再認実験において，非対称的混同効果を報告した。彼 らの仮説によると, 単純・複雑刺激はどちらもその単 純刺激に近い形式でスキーマ的に符号化される。つま り記憶表象は単純化するため, 単純刺激が複雑刺激に 変化する（追加）ほうが, 複雑刺激が単純刺激に変化 する（削除）よりも，被験者によく気づかれると説明 している.

この後に行われた, 子供を被験者とした研究 (Miranda et al., 1992) や2 次元 (シーン線画) と 3 次元（テーブルセッティング）の刺激を用いた研究 (Nallan et al., 1994) に抢いても，削除変化よりも追 加変化に対して反応時間が速く, 正答数も多いことが 示されている。また，言語材料に関しても校正課題 (Healy, 1981）やスクリプトの再認実験（Maki, 1989） において, 一貫して追加変化の優位性が報告されてい る。しかしながら, どの研究においても, Agostinelli et al. (1986) がいう比較の方向による追加変化優位 あるいは削除変化優位の効果は得られておらず，むし 
ろ Pezdek et al. (1988) の説を支持するものである。

しかしながらほとんどの先行研究において，刺激の 変化方法に問題点がある。それは，一つの刺激に何か 特徵（項目）を追加することを追加変化とし，追加刺 激からその特徴を削除することを削除変化としている 点である。そのような二つの刺激間の変化では，もし オリジナルとなる刺激が非常に典型的な概念を表すも ので, 我々の典型的記憶表象に対応したものであった 場合, 追加・削除変化だけでなく，次のような変化の 効果が再認に影響を与えると考えられる。一つは典型 的な刺激に何か特徵が追加・削除され逸脱した刺激に 変化する効果であり，もう一つはその逸脱した刺激が 余分な特徴を削除され（または足りない特徵を追加さ れ，もとの刺激に戻る変化の効果である。たとえば， Pezdek et al. (1988) の刺激に泣いているピエロの絵 がある。単純刺激は泣いているピエロの顔のみであ り, 複雑刺激では衣装のえりが追加されている。この 場合，もし単純刺激のほうが我々が内的にもつ典型的 記憶表象により類似していると仮定すると, 複雑刺激 への変化は追加変化であると同時に典型的表象からよ り逸脱した表象への変化でもある。同様に, 複雑刺激 から単純刺激への変化は，削除変化であると同時に逸 脱した表象から典型的表象への変化である。このよう に, 一連の先行研究における 2 刺激間の変化では, 追 加・削除変化の効果と典型的刺激と冕脱刺激間の変化 の効果が交絡している可能性があり, 一概に追加変化 が削除変化よりも効果をもつことを示しているとはい えない.

しかしながら例外として, 安藤・箱田（1998）の研 究がある. 彼らは先行研究で示された追加変化の優位 性と変化刺激の予測性の関連を調べた。チョウの自然 画像を刺激とし, 予測と一致しない変化刺激を作成す るため, 特徴（頭, 触角など）の一つを追加・削除し もとのチョウの形態を壊すような変化を行った。それ ら変化刺激の予想不一致度を測定し, 再認確信度との 関係を調べたが両者の間に密接な関係はなかった。一 方，ネコ画像を刺激とした研究（安藤・箱田，1999） においては削除変化優位の非対称的混同効果がみら れ, 変化刺激の印象評定值が再認確信度を予測するこ とが示された。一連の先行研究とは異なり，これら二 つの研究はもとの典型的刺激への逸脱した追加・削除 変化の検出を検討しているが，逸脱した刺激がもとの 典型的刺激に戻る効果は調べていない.

そこで本研究では，オリジナルとして設定した刺激 に対して特徴を追加した追加刺激, 特徵を削除した削 除刺激という変化刺激を作成した。オリジナル刺激か ら追加・削除刺激の方向への変化を逸脱変化，逆に， 追加・削除刺激からオリジナル刺激の方向への変化を 復元変化と呼ぶ.つまり変化の方法には，復元・追 加, 逸脱 - 追加, 復元 ・削除, 逸脱 - 削除の 4 種類が

\section{DEVIATION CHANGE}

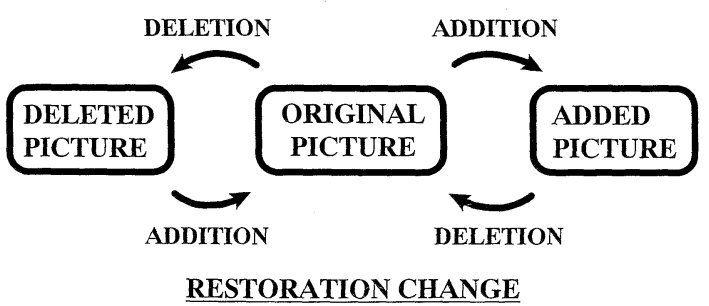

Figure 1. Types of changes. Addition and deletion applied to original picture were referred to deviation change, and those applied to changed picture were referred to restoration change.

あった（Figure 1). 逸脱・復元それぞれの変化の方 向において, 追加・削除変化の検出差を調べることに より，いわゆる非対称的混同効果が生じる機序につい て検討した。

また, 逸脱・復元変化はどのような刺激をオリジナ ル刺激とし，どのような特徴を操作するときに起こる のかについて検討した。オリジナル刺激の特性につい ては，実験 1 ではシーンの線画（例 昼寝をしている 熊の親子, サーフィンをしているウサギ), 実験 2 で は単一の対象物の線画（例 シャツ，自転車）を用い た.シーン線画は，実際のシーンを描画したものでは なくイラスト集から選んだ創作的な線画であるため, これらのオリジナル刺激に対して我々だれもが共通し て典型的記憶表象をもつとは考えられない.また，操 作した特徵は線画中の詳細情報であり，刺激の意味を 変えない程度の変化であったと考えられる。これらの ことから, 逸脱・復元変化の効果はないと予測され る.したがって，もし追加・削除変化自体に非対称な 効果があるなら，逸脱・復元にかかわらず二つの追加 変化がよりよく検出されるだろう。それに対し実験 2 で用いる単一の対象物の線画は，基本的カテゴリー (Rosch, Mervis, Gray, Johnson, \& Boyes-Bream, 1976) に属する熟知性の高い対象物の線画であり, 典型性と 関係が深いイメージ一致度 (Snodgrass \& Vanderwart, 1980）の高い線画であるため，我々はオリジナル刺激 に対してだれもが典型的記憶表象をもつと考えられ る.また, 操作した特徴はその対象の要素であり, こ の変化は刺激の意味を変える奇異な変化であったと考 えられる、これらのことから, 逸脱変化が復元変化よ りも効果をもつと考えられ，さらにこの場合にも追 加・削除変化自体に非対称な効果があるなら, 逸脱・ 復元それぞれにおいて追加変化の優位性がみられ，追 加・削除変化に非対称な効果がないならば，逸脱変化 の優位性のみが得られるだろう。

オリジナル刺激から追加・削除変化刺激への変化の 程度を統制するため, 類似性評定課題を行った。 


\section{実 験 1}

シーン線画中の詳細情報を追加・削除し，その効果 を調べる。また，オリジナル刺激に対して典型的記憶 表象をもちえないときの逸脱・復元効果について検討 する。

\section{方 法}

被験者 刺激の類似性評定課題に 24 名, 再認実験 に 40 名の被験者が参加した。

刺激 さまざまなシーンの線画 30 枚をオリジナル 刺激とし，各々につき線画に含まれる詳細情報（模 様, 明暗など）を追加・削除した変化刺激を作成し た。さらに削除刺激とオリジナル刺激，オリジナル刺 激と追加刺激を組み合わせて並べた刺激対を 30 組ず つ合計 60 組と，その左右位置を入れ替えた 60 組の合 計 120 組の刺激対を作成した。それらの刺激対につい て類似性評定課題を行った。被験者は二つの刺激を見 比べて，それらがどれくらい類似しているかを“1. 非常に類似していない”，“4. どちらでもない”，“7. 非常に類似している”の7段階で評定した。その評定 值について，30(刺激の種類) $\times 2$ (追加・削除刺激) $\times 2$ （左右位置入れ替え）の 3 要因の分散分析を行った. その結果, 評定值に追加・削除変化, 左右位置による 有意差がない刺激対，つまりオリジナル刺激から追 加・削除各変化刺激への変化の程度に統計的差のない 刺激対を 16 組選択した。選択した刺激の平均評定值 は 3.5 から 6.42 の間で，オリジナル刺激と削除刺激, オリジナル刺激と追加刺激の平均評定值はそれぞれ， $5.1(S D=0.87), 5.0(S D=0.84)$ であった.

刺激はすべて学習期と再認期とで変化させて呈示 し，4種類の変化それぞれの条件に，10 名の被験者が 参加した。たとえば, 追加・復元条件の被験者は, 学 習期に削除刺激 16 枚を学習し, 再認期にオリジナル 刺激 16 枚について判断を行った。

手続き すべての学習刺激を呈示した直後, 再認テ ストを行った。学習期には, パーソナルコンピュータ (Power Macintosh 8500/150) によりCRT 画面 (SONY Multiscan 17sf9) 上に学習刺激を 1 枚 10 秒 間ずつ，5秒の間隔をおいてランダムに呈示した。被 験者は $60 \mathrm{~cm}$ 離れた場所から視角 $9.5^{\circ} \times 9.5^{\circ}$ の大きさ の刺激を観察した。被験者には画面に現れる刺激をよ く見るよう教示した。

再認期には，16 枚のテスト刺激を 1 枚ずつ呈示し, 被験者の判断後, 次のテスト刺激を呈示した。被験者 は画面に現れる各テスト刺激を見て，それが学習期か ら“変化した”か“変化していない”かを判断した。

\section{結果と考察}

変化刺激に対する正棄却率の平均值を被験者ごとに

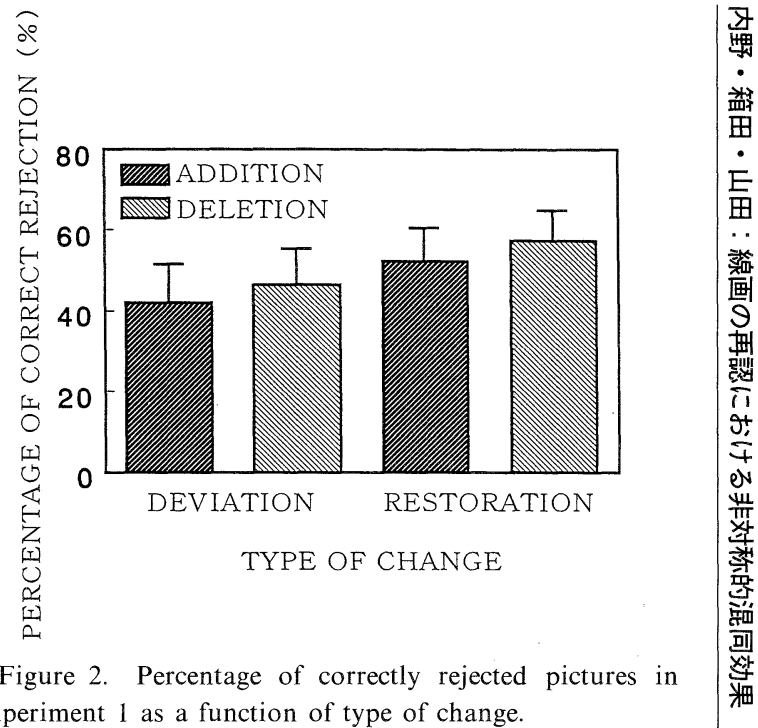

求めた，復元・追加，逸脱・追加，復元・削除，逸 脱・削除に対する正棄却率はそれぞれ，52.1\%，41.8 \%，57.5\%，46.4\%であうた（Figure 2). 各被験者の 正棄却率を角変換した值について, 2 (変化の種類：追 加 ・削除) $\times 2$ (変化の方向：復元・逸脱）の 2 要因の 分散分析を行った. その結果, 変化の種類, 変化の方 向ともに有意な効果はみられなからた。

次に，オリジナル刺激と変化刺激との類似度により 正棄却率が影響を受けるかどうかを分析した。16の 刺激対各々について，オリジナル刺激の追加刺激に対 する類似度と削除刺激に対する類似度の平均値を算出 した。その結果，16刺激のオリジナルと変化刺激と の平均類似度は 3.73 から 6.29 までの範囲であった。 類似度が低い下位五つ, 類似度が高い上位五つの刺激 に対する正棄却率を分析対象とした。 ぞれらの平均値 を Table 1 亿示す. 類似度が低い 5 刺激の平均類似度 は 4.06 $(S D=0.27)$, 高い 5 刺激の平均類似度は 6.00 $(S D=0.31)$ であった。それぞれに対する正棄却率を 各被験者ごとに算出し，角変換した值について，2(変 化の種類: 追加 $\cdot$ 削除) $\times 2$ (変化の方向: 復元 $\cdot$ 逸 脱 $) \times 2$ (類似度：低・高）の分散分析を行った結果， 類似度の主効果のみ有意であった $(F(1,36)=24.59$, $p<.001$ )。下位検定（Ryan 法）の結果，類似度が低 い刺激に対するほうが類似度が高い刺激に対するより 正棄却率が有意に高かった。

まず，逸脱・復元効果がなかったことから，実験 1 のオリジナル刺激は我々が典型的記憶表象をもつ刺激 ではなかったこと，また，詳細情報の変化ではその効 果は起こりにくいことが示唆される.さらに, 逸脱・ 復元の効果がないことから, 二つの追加・削除変化は 逸脱・復元の効果にかかわらない追加・削除のみの効 
Table 1

Percentage at correctly rejected pictures as a functionof type of change and similarity in two experiments

\begin{tabular}{|c|c|c|c|c|c|c|c|c|}
\hline \multirow[b]{3}{*}{ Similarity } & \multicolumn{4}{|c|}{ Addition } & \multicolumn{4}{|c|}{ Deletion } \\
\hline & \multicolumn{2}{|c|}{ Restoration } & \multicolumn{2}{|c|}{ Deviation } & \multicolumn{2}{|c|}{ Restoration } & \multicolumn{2}{|c|}{ Deviation } \\
\hline & Low & High & Low & High & Low & High & Low & High \\
\hline Exp. 1 & 70 & 34 & 48 & 34 & 62 & 48 & 54 & 42 \\
\hline Exp. 2 & 90.7 & 59.3 & 93.5 & 90.7 & 88.9 & 67.6 & 97.2 & 72.2 \\
\hline
\end{tabular}

果とみなすことができる。しかしながら，逸脱・復元 どちらにおいても非対称的混同効果はみられなかっ た。これは, 実験 1 のような詳細情報の変化では，追 加・削除変化自体に非対称な効果がないことを示唆す る。また，どの変化においても類似度が低い刺激のほ うが高い刺激よりもよく棄却された。類似度はオリジ ナル刺激からの変化の程度を反映していると考えられ るため，オリジナルからの変化の程度が大きい刺激の ほうが気づかれることが示された。

それではなぜ，本実験と同様に刺激中の詳細情報を 操作した研究 (Agostinelli et al., 1986; Pezdek et al., 1988）や，シーンの線画を用いた研究（Miranda et al., 1992; Nallan et al., 1994）において, 非対称的混 同効果が認められたのか. 先にも指摘したとおり，先 行研究における変化方法は一つの刺激を基点においた 追加・削除変化ではなく, 一つの刺激に特徴を追加す ることを追加変化，その追加刺激から特徴を削除する ことを削除変化としている，さらに，詳細情報や一つ の項目の追加・削除による刺激変化は予測されない変 化ではなかったとしているが，実験的に確認してはい ない.したがって，オリジナル刺激の特性や操作した 特徴が逸脱・復元の効果を及ぼさないものであったと は断定しがたい.つまり，オリジナル刺激が非常に典 型的であった可能性，さらに刺激の意味を変えるよう な刺激変化を行った可能性がある。もしそうならば, 先行研究では逸脱による追加と復元による削除，また は復元による追加と逸脱による削除を比べて，追加・ 削除変化に非対称な効果があると示しているにすぎ ず，追加・削除変化自体の効果を議論しているとはい えない.

そこで実験 2 では，単一の対象物の線画をオリジナ ル刺激とし，その要素を追加・削除した変化刺激を作 成した。オリジナルとなる対象物の線画は, Snodgrass and Vanderwart (1980) が画像材料の標準 化のために作成した刺激の中から，松川（1983）によ るイメージ一致度などの調査に基づいて選択した。イ メージ一致課題とは, 被験者に対象の名前を与えその 対象をイメージさせた後，画面に現れる画像がそのイ メージとどれくらい一致するかを評定させた課題であ る。したがって，実験 2 のオリジナル刺激は我々がそ
の対象について典型的にもつ表象に近い刺激であり， その要素を追加・削除した変化刺激は逸脱性が高いと 考えられる.以上のことから，実験 2 においては逸 脱・復元効果が現れることが想定される.

\section{実 験 2}

単一の対象物の線画において，その要素を追加・削 除し，その変化の効果を調べる。また，我々がもつ典 型的記憶表象に近いと考えられるオリジナル刺激を用 いることにより，逸脱・復元の効果を検討する。

\section{方 法}

被験者 類似性評定課題に 20 名，再認課題に 36 名 の被験者が参加した。

刺激 Snodgrass and Vanderwart (1980) が画像材 料の標準化のために作成した 260 枚の画像刺激から， 松川（1983）の報告に基づき刺激を選択した。260枚 の刺激は単一の対象を表す線画（自転車，電話，手， ネズミなど）であった。松川（1983）はこれらの線画 刺激について, 命名一致課題・熟知度評定課題・視覚 的複雑さの評定課題 (1. 非常に単純，5. 非常に複 雑)・イメージ一致課題（1.イメージと絵との一致度 が低い，5.イメージと絵との一致度が高い）などを 日本人被験者について行った。

本実験では，この松川（1983）の実験結果に基づ き, 命名困難とされた 31 画像を除いた 229 画像のう ち, イメージ一致度の評定值が 4 以上かつ視覚的複雑 さの評定值が 2 -4 である 53 画像をオリジナル刺激の 候補とした。変化刺激は，オリジナルの対象がもつ要 素 (部分) の一つを削除または追加して作成した。も ともと少ない要素をもつ対象はその要素を削除した変 化刺激が同定困難であったため除外した。結果として 32 のオリジナル刺激を用いた。追加・削除刺激は, 一つのオリジナル刺激について，変化させる要素が異 なる 2 パタンを作成した。

さらに, 実験 1 と同様の類似性評定課題を行った. オリジナル刺激と削除刺激，オリジナル刺激と追加刺 激をそれぞれ並べた刺激対を 64 組，その左右を入れ 替えた 64 組の合計 128 組の刺激対を 2 パタンの変化 刺激について作成した。各パタンについて 10 名ずつ 
の被験者が類似性評定課題を行った。各パタンにつ き，32(刺激の種類) $\times 2$ (追加・削除刺激) $\times 2$ (左右位 置入れ替え）の 3 要因の分散分析を行った結果, 評定 值に変化の種類, 左右位置による有意差がない 24 組 の刺激対を選択した。一つのオリジナル刺激に関し て, 変化させた部分が異なる 2 パタンの変化刺激が選 択されることはなかった。類似度の範囲は 1.9 から 5.8 まで，オリジナル刺激と削除刺激，オリジナル刺 激と追加刺激の類似度の平均值はそれぞれ，3.75 $(S D=1.26) ， 3.67(S D=1.28)$ であった。

24 組の刺激対は学習期と再認期とで変化させて呈 示した (変化呈示刺激). 実験 1 と同様に, 逸脱・復 元それぞれによる追加・削除変化の 4 種類の変化があ つた。

学習期と再認期とで変化させずに呈示する刺激を, 最初にオリジナル刺激候補として選択した 53 枚の画 像のうち, 変化呈示刺激として用いない画像から 12 枚選択した。そのうち，4 枚はオリジナル刺激とし て, 残りについては追加・削除刺激を 4 枚ずつ作成 し, それを無変化呈示刺激とした。実験 1 とは異な り, 実験 2 の変化刺激はもとの刺激の意味を変えるよ うな, 典型的記憶表象から逸脱した刺激であると考え られる。その逸脱した追加・削除刺激の間において, 再認のされやすさに差があるかどうかを調べるために 無変化呈示刺激を用意した。

追加・削除は被験者間変数, 逸脱 - 復元は被験者内 変数とした。具体的には, 学習期に変化呈示刺激とし て, 追加条件では削除刺激 12 枚, オリジナル刺激 12 枚, 削除条件では追加刺激 12 枚, オリジナル刺激 12 枚を呈示した。再認期には, 追加条件ではオリジナル 刺激 12 枚, 追加刺激 12 枚, 削除条件ではオリジナル 刺激 12 枚, 削除刺激 12 枚を呈示した. また, 無変化 呈示刺激として, オリジナル・削除・追加刺激を 4 枚 ずつ, 学習期と再認期に変化させずに両条件ともに呈 示した。計 36 枚の刺激を学習期・再認期ともにすべ てランダムに呈示した。

手続き 刺激の呈示時間と呈示間隔を除いては，実 験 1 と同じ手続きであった. 36 枚の各刺激は 1 枚 5 秒間ずつ，3秒の間隔をおいてランダムに呈示した。

\section{結果と考察}

まず，変化呈示刺激への正棄却率の分析を行った。 復元・逸脱変化への正棄却率の平均值は追加条件で $75 \% ， 92.1 \%$ ，削除条件で $78.2 \% ， 84.7 \%$ であった (Figure 3). 各被験者の正育却率を角変換した值につ いて, 2(変化の種類：追加・削除) $\times 2$ (変化の方向： 復元・逸脱）の 2 要因の分散分析を行った。その結 果, 変化の方向の主効果, 二つの要因の交互作用が有 意であった（それぞれ， $F(1,34)=25.87, p<.001$ ， $F(1,34)=6.06, p<.05)$. 下位検定（Ryan 法）によ
Figure 3. Percentage of correctly rejected pictures in Experiment 2 as a function of type of change.

り, 逸脱変化において追加変化が削除変化より有意に 正しく棄却され, 追加変化に打いて逸脱変化が復元変 化より有意に正しく棄却されたことがわかった（それ ぞれ, $F(1,68)=4.13, p<.05, F(1,34)=28.48, p<$ $.001)$.

次に無変化呈示刺激についての正再認率の分析を行 った。削除・オリジナル・追加刺激への正再認率の平 均值は追加条件で $80.6 \%, 87.5 \%, 93.1 \%$, 削除条件

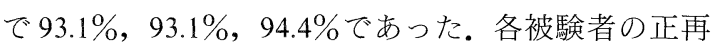
認率を角変換した值について, 2(追加・削除条件) $\times 3$ (削除・オリジナル・追加刺激）の 2 要因の分散分析 を行ったが, 主効果, 交互作用とも有意差はなかっ た。

さらに，類似度による正棄却率の分析を行った。実 験 1 と同様, オリジナル刺激と各変化刺激に対する類 似度の平均値を算出した結果, 平均類似度の範囲は 1.98 から 5.70 であった。追加・削除各条件において, 逸脱・復元変化を加えたそれぞれの 12 刺激のうち, 類似度が低い 6 刺激と類似度が高い 6 刺激を分析対象 とした。類似度が低い 6 刺激の平均類似度は 3.05 $(S D=0.59)$, 高い 6 刺激の平均類似度は $4.77(S D=$ 0.76)であった。それぞれに対する正棄却率を各被験 者ごとに算出し (Table 1 参照), 角変換した值につ いて, 2 (追加 - 削除) $\times 2$ (復元 - 逸脱 $) \times 2$ (類似度： 低・高）の分散分析を行った。その結果, 復元・逸脱 と類似度の主効果（それぞれ， $F(1,34)=23.34, p<$ $.001, F(1,34)=59.33, p<.001)$, その二つの交互作用 $(F(1,34)=5.26, p<.05), 3$ 要因の交互作用 $(F(1$, $34)=14.09, p<.001)$ が有意であった。下位検定 （Ryan 法）により，復元よりも逸脱に対する正棄却 率が有意に高く，類似度が高い刺激に対するよりも低 
い刺激に対するほうが正棄却率が高いことが明らかに なった。また，その 2 要因の単純主効果の検定では, 類似度が低い刺激よりも高い刺激におけるほうが逸 脱・復元の効果が大きいことが明らかになった。さら に, 3 要因の単純・単純主効果の検定においては, 追 加条件の逸脱に扔いてのみ類似度が効果をもたないこ とがわかった。

まず，正棄却率の分析において, 復元変化よりも逸 脱変化のほうがよく気づかれたことから, 典型的刺激 から逸脱刺激への変化のほうが, 逸脱刺激から典型的 刺激に戻る変化よりも变化の検出に効果をもつことが 確認された. さらに，逸脱変化において非対称的混同 効果が起こったことから, 逸脱する方向への追加変化 が逸脱する方向への削除変化より効果をもつことが示 された.

また, 類似度の分析において, 逸脱・追加変化以外 の変化は類似度の効果を受けることが見いだされた。 つまり, 他の変化は変化の程度が大きいときのほうが 小さいときより正しく棄却されているけれども, 逸 脱・追加変化は変化の大小に影響を受けないというこ とである.このことは, 逸脱・追加変化の頑健な効果 を示すものである。

以上の結果から, 逸脱・復元の効果がある刺激変化 では, 逸脱に扔いてのみ非対称的混同効果が起こるこ とが示された，それではなぜ，同じ逸脱刺激への変化 において, 追加変化が削除変化よりも再認に効果をも つのであろうか. 実験 2 の変化刺激は, 一つの対象物 に何か余分な特徵が追加されたり, 本来あるはずの特 徵が削除された刺激であった。そのような刺激に対し て我々は何か奇異な印象をもつことが生物画像を用い た研究により示されている（安藤・箱田, 1998, 1999)。 そのことから, 逸脱方向への追加変化優位と いう実験 2 の結果の背景に, そのような奇異な印象が 影響を及ぼしている可能性が考えられる。つまり, 変 化刺激に対する印象は, 削除刺激と追加刺激で差があ るのではないだろうか.

そこで実験 3 では, 実験 2 で用いた変化刺激の印象 評定を行い，追加刺激と削除刺激の印象を比較するこ とによりこの点を検討する。

\section{実 験 3}

実験 2 で用いた変化刺激の印象評定を行い, 追加・ 削除刺激の印象を比較する。

\section{方 法}

被験者 7 名の被験者が自由記述課題を，別の 53 名の被験者が印象評定課題を行った。

刺激 実験 2 で用いた追加・削除刺激 56 枚につい て, 印象評定を行った。各刺激を B5 判の用紙 1 枚に つき縦に二つ印刷し, 冊子を作成した。冊子には刺激
の呈示順が異なる 5 パタンがあった。

印象評定に用いる形容詞項目は, 安藤・箱田 （1999）がネコ画像の追加・削除刺激の評定に用いた ものを参考にした。まず，7名の被験者に 56 枚の変 化刺激に対する自由記述を行わせ，そのなかから出現 頻度の高い 8 項目を選択した。そして, 安藤・箱田 （1999）の 24 項目の形容詞から，先の自由記述に一度 も出現しなかった 8 項目を除き，新たに選択した上記 8 項目を追加し, 計 24 項目を使用した。これら 24 項 目の形容詞についても，順番をランダムに並べ替え， 5 パタンの冊子を作成した:

手続き 被験者は 56 枚の刺激に対して，24 項目の 印象評定を行った。被験者は各刺激を観察し，それぞ れの形容詞について SD 法形式の7 段階評定を行つ た。

\section{結果と考察}

まず，評定値について因子分析（反復主因子法，プ ロマックス回転）を行い，因子負荷量が 2 因子にわた り高い項目を除き，21 項目 3 因子を抽出した。“実用 的な”，“便利そうな”などの項目を含む第 1 因子には “実用性”と命名した。“奇妙な”，“不思議な”などの 項目を含む第 2 因子には“奇異性”, さらに“面白 い”，“感じがよい”などを含む第 3 因子には“魅力 性”と命名した。

次に，56 枚の各刺激について各因子ごとに被験者 の平均評定値を算出した。さらに，その值を追加・削 除刺激について平均し, 各因子ごとに 1 要因（変化の 種類：追加・削除）の分散分析を行った。 その結果, 三つの因子それぞれにおいて変化の種類の主効果がみ られた。実用性因子では, 追加刺激 $(M=4.91)$ より も削除刺激（M=5.05）に対する評定值が有意に高か つた $(F(1,52)=8.56, p<.01)$ 。つまり，追加刺激の ほうが削除刺激よりも実用的で意味があると判断され た。奇異性因子では, 追加刺激 $(M=3.42)$ よりも削 除刺激 $(M=3.65)$ に対する評定值が有意に高く（ $F$ $(1,52)=23.68, p<.001)$, これは追加刺激のほうがよ り奇妙で不気味であると判断されたことを意味する。 さらに，魅力性因子に関しては追加刺激 $(M=4.49)$ よりも削除刺激 $(M=4.65)$ に対する評定值が有意に 高く $(F(1,52)=14.54, p<.001)$, 追加刺激のほうが より興味を引くものと判断されたことがわかった。

これらの結果をまとめると, 追加刺激は削除刺激に 比べて，より奇妙であるがなんらかの役に立ちそうな 面白いものという印象を被験者に抱かせていることが わかる。

それでは，追加刺激と削除刺激に対するそのような 印象の違いが, 逸脱方向への追加・削除変化に対する 非対称な検出結果にどのように影響を与えるのだろう か. 逸脱方向への追加・削除変化では，学習期に見る 
刺激は通常の形態をした対象物である。そして, 再認 期に見る何か余分な特徵がついた対象物, あるいはあ るはずの特徵が欠けた対象物について印象の差が生じ る。そこに扔いて, 追加刺激に対する印象のほうが, “変化した”という判断をより増すのに影響すると考 えられる. 一方, 追加・削除刺激が学習刺激となる復 元変化では非対称な検出差はなかった.このことか ら, 学習期に知覚される印象は再認期の判断には影響 を及ぼさないと考元られる。

\section{全体的考察}

まず，実験 1 と 2 の結果より，オリジナル刺激の特 性と操作する特徵の種類の点から, 先行研究でみられ た非対称的混同効果に関する考察を行う.

実験 1 に扔いて逸脱・復元の効果がなかったことか ら,オリジナル刺激に用いたシーンの線画は, 典型的 記憶表象を我々がもつようなものではなく,さらに詳 細情報を操作した変化刺激は奇異な印象を与えるもの ではなかったと考えられる。そこにおいて，非対称的 混同効果が起こらなかったことは, 画像の意味にあま り関係のない詳細情報の追加・削除変化には非対称な 効果がないことを示唆する.このことは, 画像の再認 において詳細情報があまり役立つものではないという 見解と一致している (Nelson, Metzler, \& Reed, 1974). しかしながら, 詳細情報を操作した非対称的混同効果 の先行研究 (Agostinelli et al., 1986; Pezdek et al., 1988）と一致する結果ではない.

対照的に実験 2 では, 我々が典型的にもつ記憶表象 に近いと考えられる対象物の線画をオリジナル刺激と し, 操作する特徴はその対象物の要素であった. 予測 どおり, 逸脱変化は復元変化よりも変化の検出に効果 をもち, さらに非対称的混同効果は逸脱変化において のみ認められた。このことにより, 典型的な刺激が逸 脱した刺激へ変化する場合に, 追加・削除変化が非対 称な効果をもつことが示された。 また, この逸脱・追 加変化の効果は類似度による分析から, オリジナル刺 激からの変化の程度にかかわらない, かなり頑健な効 果であることが示された。これに関しては, Maki （1989）のスクリプトの再認実験にも同様の効果がみ られる。その実験では, 予測性の低い詳細情報の追加 は予測性の高い詳細情報の追加よりょく検出され,一 方, 削除変化では予測性は効果をもたなかった。この 予測性は, 本研究に打ける逸脱・復元変化に対応させ て考えることができる。つまり, 予測性が低いと考え られる逸脱・追加変化が, 予測性が高いと考元られる 復元・追加変化よりもよく検出されたという結果と一 致する.また, 予測されない対象物への変化は予測さ れる対象物への変化よりも気づかれやすいという Friedman（1979）の研究結果とも一致するものであ る.
以上実験 1 と 2 の結果から, 先行研究の非対称的混 同効果は, 逸脱方向への追加変化と, 復元方向への削 除変化をとらえて, 追加変化が削除変化より気づかれ やすいとしたものである可能性が示唆される. しかし ながら, 実験 1 と 2 では, オリジナル刺激の特性, 操 作する特徵の種類の両方が異なるために, 二つの実験 結果の違いはどちらによるものであるか特定ができな い.つまり，オリジナル刺激に対して典型的表象をも ちえない場合にも, 逸脱・復元の効果を生じさせる刺 激の意味を変える変化が可能であるし, オリジナル刺 激に対して典型的記憶表象をもちうる場合にも，刺激 の意味を変えない変化が可能である，この点は今後の 重要な検討課題である.

次に, 実験 2 で用いた変化刺激の印象評定の結果, 実用性, 奇異性, 魅力性の 3 因子が抽出され, 追加刺 激と削除刺激では印象に差があることが示された。こ のことから, 逸脱変化における非対称的混同効果は, 変化刺激の異なる印象に起因する可能性が示唆され た. 同様に，ネコ画像の変化刺激の印象を調べた安 藤・箱田 (1999) の研究では, 現実・典型性, 安定・ 均衡性, 嫌悪・怪奇性因子が抽出され, 変化の検出が 変化刺激の印象の差によるという結果を得ている。し かしながら, 彼らの実験では削除変化のほうが正棄却 率が高く, 本研究とは逆の結果であった。この原因と して, 彼らの刺激はネコという一般的に身近に接する 動物の自然画像であるのに対し, 本研究の刺激は大部 分が “もの”である対象物の線画であるというオリジ ナル刺激の特性の違いが考えられる. 印象評定の結果 を具体的に比較してみると, より奇妙であると判断さ れたのは両研究ともに追加刺激であるが, より現実的 であると判断されたのは, 安藤・箱田（1999）では削 除刺激, 本研究では追加刺激である.つまり, 生物画 像では追加刺激はより奇妙で現実的ではない, 対象物 では追加刺激はより奇妙だが現実的であると判断され た違いがある。このことから, 生物画像と対象物の線 画では, ぞちらにも追加刺激と削除刺激の間に印象の 差が生じるが, 印象に及ぼす追加・削除刺激の効果は 異なると考えられる。この違いが再認にも異なる影響 を及湾したのではないだろうか。また, 安藤・箱田 （1999）は冕脱方向への追加・削除変化を調べている. つまり, 被験者は学習期には変化刺激を観察しておら ず, 学習段階での変化刺激の印象差が変化の検出に関 与しているとは考えられない.この点に関しては, 学 習期に変化刺激を観察する本実験の復元による追加・ 削除変化に差がないことから, 変化刺激の印象は学習 期ではなく再認期の判断に影響を与えることが示唆さ れる。

本研究では, 線画の再認実験において従来みられて いた追加変化の優位な効果の背景に, 逸脱・復元とい う典型的刺激と逸脱刺激間の変化の効果が交絡する可 
能性を示した。また，非対称的混同効果は，再認期に おける変化刺激の印象による効果である可能性が示唆 された。

\section{引用文献}

安藤満代・箱田裕司 1998 蝶画像の再認記憶におけ る非対称的混同効果 心理学研究, 69, 47-52.

(Ando, M., \& Hakoda, Y. 1998 Asymmetric confusability effects in recognition memory of butterfly pictures. Japanese Journal of Psychology, 69, 4752.)

安藤満代・箱田裕司 1999 ネコ画像の再認記憶にお ける非対称的混同効果 心理学研究, 70, 112-119.

(Ando, M., \& Hakoda, Y. 1999 Asymmetric confusability effect in recognition memory of cat pictures. Japanese Journal of Psychology, 70, 112119.)

Agostinelli, G., Sherman, S. J., Fazio, R. H., \& Hearst, E.S. 1986 Detecting and identifying change: Additions versus deletions. Journal of Experimental Psychology: Human Perception and Performance, 12, 445-454.

Friedman, A. 1979 Framing pictures: The role of knowledge in automatized encoding and memory for gist: Journal of Experimental Psychology: General, 108, 316-355.

Healy, A. F. 1981 The effects of visual similarity on proofreading for misspellings. Memory and Cognition, 9, 453-460.

Maki, R. H. 1989 Recognition of added and deleted details in scripts. Memory and Cognition, 17, 274282.
松川順子 1983 画像材料の諸特性の検討(1)：Snodgrass \& Vanderwart の画像を用いて 島根大学法文 学部文学科紀要, 6-1, 97-139.

Miranda, N., Jackson, L. S., Bentley, D. M., Gash, G. H., \& Nallan, G. B. 1992 Children discover addition more easily and faster than deletion. Psychological Record, 42, 117-129.

Nallan, G. B., Bentley, D. M., Carr, J. F., Lyons, K., Moore, D. S., \& Underhill, T. 1994 Adult humans perform better on addition than deletion problems. Psychological Record, 44, 489-499.

Nelson, T. O., Metzler, J., \& Reed, D. A. 1974 Role of details in the long-term recognition of pictures and verbal descriptions. Journal of Experimental Psychology, 102, 184-186.

Pezdek, K., Maki, R., Valencia-Laver, D., Whetstone, T., Stoeckert, J., \& Dougherty, T. 1988 Picture memory: Recognizing added and deleted details. Journal of Experimental Psychology: Learning, Memory, and Cognition, 14, 468-476.

Rosch, E., Mervis, C. B., Gray, W. D., Johnson, D. M., \& Boyes-Bream, P. 1976 Basic objects in natural categories. Cognitive Psychology, 8, 382-439.

Snodgrass, J. G., \& Vanderwart, M. 1980 A standardized set of 260 pictures: Norms for name agreement, image agreement, familiarity, and visual complexity. Journal of Experimental Psychology: Human Learning and Memory, 6, 174-215.

Tversky, A. 1977 Features of Similarity. Psychological Review, 84, 327-352.

- 1999.1.18 受稿, 1999.9.11 受理—— 